\title{
Testosterone Administration Suppresses Adiponectin Levels in Men
}

\author{
STEPHANIE T. PAGE,* KAREN L. HERBST, $\dagger$ JOHN K. AMORY,* ANDREA D. COVIELLO,* \\ BRADLEY D. ANAWALT,* $*$ ALVIN M. MATSUMOTO,* $\ddagger \S$ AND WILLIAM J. BREMNER* \\ From the *Department of Medicine, §Veterans Affairs-Puget Sound Health Care System, and $\$$ Geriatric Research \\ Education and Clinical Center, University of Washington School of Medicine, Seattle, Washington; and the \\ $\dagger$ Department of Medicine, Charles Drew University, University of California at Los Angeles School of Medicine, \\ Los Angeles, California.
}

\begin{abstract}
Testosterone ( $\mathrm{T})$ administration to men increases lean body mass and decreases fat mass. Adiponectin is produced by adipocytes and is thought to influence insulin sensitivity. In this study, we sought to determine whether experimental alterations in serum $\mathrm{T}$ change adiponectin levels in normal men. We measured adiponectin levels in 28 healthy men ages 18-35 years before and during treatment with a potent gonadotropin-releasing-hormone $(\mathrm{GnRH})$ antagonist, acyline. Decreased $\mathrm{T}$ levels led to increased serum adiponectin within 7 days; maximal adiponectin levels were reached on day 21 (baseline $8.6 \pm 0.9$ compared with $12.2 \pm 1.0$ $\mu \mathrm{g} / \mathrm{mL}$ on day $21, P<.05)$ and persisted through day 30 , despite no significant changes in body mass index (BMI) and an increase in leptin. The addition of $T$ to acyline, maintaining serum $T$ levels within the normal range, prevented the increase in adiponectin following
\end{abstract}

acyline alone. In a second study, 25 men aged 55-85 years were treated with 3 weeks of high-dose $\mathrm{T}$ (testosterone enanthate [TE], $600 \mathrm{mg} / \mathrm{wk}$ intramuscularly). With high serum T levels, adiponectin levels decreased significantly by day 21 of treatment (baseline 14.3 \pm 1.9 compared with $10.8 \pm 1.5 \mu \mathrm{g} / \mathrm{mL}, P<.05$ vs baseline and placebo), BMI slightly increased, and leptin levels were decreased. We conclude that adiponectin levels increase within days of experimental T deficiency in normal men, and the increase in adiponectin is prevented by T replacement. Furthermore, supraphysiologic T administration results in decreased adiponectin levels. Our data support the hypothesis that $\mathrm{T}$, its metabolites, or both directly suppress adipocyte production of adiponectin.

Key words: Androgen, hypogonadal, leptin.

J Androl 2005;26:85-92
$\mathrm{T}$ estosterone (T) regulates many important physiologic processes, including muscle and fat metabolism, sexual development and function, erythropoiesis, and bone metabolism (Snyder et al, 2000). Both T replacement therapy for hypogonadism and supraphysiologic administration of $\mathrm{T}$ are associated with increases in lean body mass, decreases in fat mass, and increases in muscle strength (Bhasin et al, 1996, 1997; Bhasin et al, 2001; Gruenewald and Matsumoto, 2003). T administration reduces overall fat mass (Woodhouse et al, 2004) and has been reported to decrease central adipose stores, the fat depot most closely associated in epidemiologic studies

Supported by the NICHHD/NIH through Cooperative agreement U54HD-12629 as part of the specialized Cooperative Centers Program in Reproduction Research. A portion of this work was conducted through the Clinical Research Center Facility at the University of Washington and supported by NIH grant MO1-RR-00037. S.T.P. was supported by NIH grant HL007028.

S.T.P. and K.L.H. contributed equally to this work and should both be considered first authors.

Correspondence to: Stephanie T. Page, University of Washington Medical Center, Division of Endocrinology and Metabolism, 1959 NE Pacific, Box 357138, Seattle, WA 98195 (e-mail: page@u.washington.edu).

Received for publication June 12, 2004; accepted for publication August 17, 2004. with the development of insulin resistance and cardiovascular disease (Marin et al, 1992a,b; Lovejoy et al, 1995; Herbst et al, 2003b).

Adiponectin is a recently characterized $30-\mathrm{kd}$ protein secreted by adipocytes. It has sequence homology to collagen and $\mathrm{C} 1 \mathrm{q}$ and is structurally related to the tumor necrosis factor alpha cytokine family (Haffner et al, 1996; Shapiro and Scherer, 1998; Berg et al, 2002). Adiponectin levels are almost always decreased with obesity (Rajala and Scherer, 2003), and an inverse relationship between serum adiponectin levels and body mass index (BMI) has been observed in monkeys and humans (Arita et al, 1999; Hotta et al, 2000, 2001; Berg et al, 2002). In addition, in humans, adiponectin levels correlate inversely with fat mass, particularly abdominal fat mass, in cross-sectional studies (Nishizawa et al, 2002; Cnop et al, 2003). Adiponectin appears to play a role in the regulation of insulin sensitivity (Arita et al, 1999; Hotta et al, 2000, 2001; Yang et al, 2001). Administration of recombinant adiponectin decreases plasma glucose levels in both normal and diabetic mice and improves insulin sensitivity in lipotrophic mice (Yamauchi et al, 2001). Similarly, adiponectindeficient animals (adipo -/-) are moderately insulin resistant (Kubota et al, 2002). Although adiponectin has not 
yet been administered to humans, increased adiponectin levels are associated with weight loss (Hotta et al, 2000; Yang et al, 2001; Esposito et al, 2003) and thiazolidinedione treatment (Maeda et al, 2001; Yu et al, 2002), interventions that alter body composition and improve insulin sensitivity.

The relationship between adiponectin and $\mathrm{T}$ in humans has not been well characterized. Higher adiponectin levels are consistently found in women when compared with BMI and age-matched men (Arita et al, 1999; Nishizawa et al, 2002; Cnop et al, 2003), even when matched for intra-abdominal adiposity, a marker that negatively correlates with adiponectin levels (Cnop et al, 2003). In mice, castration increased adiponectin levels and insulin sensitivity, effects neutralized by the coadministration of $\mathrm{T}$, whereas ovariectomy had no effect on female mice (Nishizawa et al, 2002), implying a role for $\mathrm{T}$ in adiponectin regulation in male mice. This observation is further supported by in vitro experiments, suggesting that $\mathrm{T}$ administration results in decreased secretion of adiponectin by 3T3-L1 adipocytes (Nishizawa et al, 2002) and the recent observation that $\mathrm{T}$ replacement for 6 months in young, hypogonadal men results in decreased adiponectin levels (Lanfranco et al, 2004). Together, these studies suggest that $\mathrm{T}$ might negatively regulate adiponectin production or serum half-life.

In this study, we hypothesized that suppression of endogenous $\mathrm{T}$ in normal men would result in increased serum adiponectin levels whereas administration of supraphysiologic doses of $\mathrm{T}$ would decrease adiponectin levels, consistent with the adiponectin data in mice (Nishizawa et al, 2002). In addition, we asked whether these changes are associated with changes in leptin, as a marker of fat mass, or BMI.

\section{Materials and Methods}

\section{Acyline}

Acyline, a 10-amino acid peptide that acts as a GnRH antagonist (Herbst et al, 2002), was originally synthesized by Jean Rivier at the Salk Institute and is being distributed by the National Institute of Child Health and Human Development (NICHD). Acyline lyophilized powder was suspended in bacteriostatic water to a final concentration of $2 \mathrm{mg} / \mathrm{mL}$. In all cases, acyline was administered by subcutaneous injection in the abdomen as previously described (Herbst et al, 2002).

\section{Subjects}

Serum adiponectin levels were retrospectively obtained from serum samples stored at $-20^{\circ} \mathrm{C}$, which had not been thawed previously. Exclusion criteria in all studies included known prostate cancer; diabetes mellitus; severe liver, kidney, or musculoskeletal disease; substance abuse; and use of anabolic steroids, an- drostenedione, dehydroepiandrosterone (DHEA), or growth hormone.

Study 1-Twenty-one normal, healthy, eugonadal volunteers ages $18-50$ years were randomized to treatment with acyline in various doses (Herbst et al, 2004). Seven eugonadal men who received $\mathrm{T}$ in addition to acyline in a separate study described elsewhere (Coviello et al, submitted) were included in the analyses to examine BMI and adipokines. There were no subjects lost to treatment once drug administration was initiated.

Study 2-Twenty-nine men aged 55-85 years were recruited and randomized to testosterone enanthate (TE; Schein Pharmaceuticals, Florham Park, NJ; $n=13)$ or placebo $(n=12)$ administration prior to knee or hip replacement as previously described (Amory et al, 2002; Herbst et al, 2003a). Samples were obtained in these outpatients 3 weeks (baseline) and 1 day prior to undergoing elective joint replacement; postoperative samples were not included in the analyses. Four subjects were excluded from the analyses on the basis of established diabetes mellitus managed with oral hypoglycemics (although inclusion of their values in the analyses did not change any of the significant results).

\section{Protocols}

Study 1-Subjects were treated with various doses of acyline (300 $\mu \mathrm{g} / \mathrm{kg}$ once, $75 \mu \mathrm{g} / \mathrm{kg}$ every 4 days $\times 3$, or $75 \mu \mathrm{g} / \mathrm{kg}$ every other day $\times 5$ for a total dose of 225-375 $\mu \mathrm{g} / \mathrm{kg}$; Acyline, $\mathrm{n}=$ 21) or, in a separate study, with acyline $300 \mu \mathrm{g} / \mathrm{kg}$ on day $0+$ TE $100 \mathrm{mg} / \mathrm{wk}$ on days $0,7,14$, and 21 as described elsewhere (Acyline + TE, $\mathrm{n}=7$; Herbst et al, 2004; Coviello et al, submitted). Subjects receiving Acyline alone were combined into a single group because all dosage groups produced a similar decline in serum $\mathrm{T}$ to castrate levels with similar kinetics (within 24 hours of acyline administration; Herbst et al, submitted). Blood sampling was performed on days $0,2-3,4,6-7,14-15$, 21, and 28-30.

Study 2-Participants were randomized to receive either TE $600 \mathrm{mg}$ in $3 \mathrm{~mL}$ of sterile sesame oil intramuscularly (IM) every week $(\mathrm{n}=13)$ or a placebo of $3 \mathrm{~mL}$ of sterile sesame oil IM every week $(n=12)$ on days 0,7 , and 14 as previously described (Amory et al, 2002). Blood samples were collected before injections on days $0,7,14$ (baseline), and 21 in all subjects except a subset of men $(n=9)$ for which all 4 blood samples were collected after a 12-hour overnight fast (Herbst et al, 2003a).

The Institutional Review Board of the University of Washington and the Veterans Affairs Research and Development Committee approved the studies, and subjects gave written informed consent prior to screening in all cases.

\section{Measurements}

Testosterone- $\mathrm{T}$ levels were measured by immunofluorometric assay (Delfia, Wallac Oy, Turku, Finland, for subjects receiving Acyline alone or high-dose T; Diagnostic Products Corporation [DPC], Los Angles, Calif, for subjects receiving Acyline $+\mathrm{T}$ ). All samples from a given individual were included in duplicate in a single assay. The Delfia assay sensitivity was $0.5 \mathrm{nmol} / \mathrm{L}$. For low, mid, and high pooled values of 3.8, 10.6, and $24.4 \mathrm{nmol} / \mathrm{L}$, respectively, the intra-assay coefficients of varia- 
Table 1. Baseline parameters of subjects in study 1 (mean \pm SEM)*

\begin{tabular}{lcc}
\hline & Acyline & Acyline + TE \\
\hline $\mathrm{n}$ & 21 & 7 \\
Age $(\mathrm{y})$ & $28.1 \pm 1.5$ & $22.6 \pm 1.6$ \\
$\mathrm{BMI}\left(\mathrm{kg} / \mathrm{m}^{2}\right)$ & $26.0 \pm 0.8$ & $23.7 \pm 0.9 \dagger$ \\
$\mathrm{T}(\mathrm{nmol} / \mathrm{L})$ & $22.4 \pm 1.7$ & $14.3 \pm 1.6 \dagger$ \\
Adiponectin $(\mu \mathrm{g} / \mathrm{mL})$ & $8.6 \pm 0.9$ & $9.3 \pm 1.1$ \\
Leptin $(\mathrm{ng} / \mathrm{mL})$ & $5.9 \pm 1.0$ & $2.2 \pm 0.5 \dagger$ \\
\hline
\end{tabular}

${ }^{*} \mathrm{BMI}$ indicates body mass index; $\mathrm{T}$, testosterone; and TE, testosterone enanthate.

$\dagger P<.05$ vs Acyline alone.

tion were $9.6 \%, 5.2 \%$, and $6.1 \%$ and the interassay coefficients of variation were $12 \%, 8.2 \%$, and $6.7 \%$, respectively. The DPC assay sensitivity was $0.35 \mathrm{nmol} / \mathrm{L}$. For low, mid, and high pooled values, the intra-assay coefficients of variation were $10.0 \%$, $5.3 \%$, and $6.6 \%$ and the interassay coefficients of variation were $13.6 \%, 6.1 \%$, and $6.8 \%$ respectively.

Adiponectin-For all samples, adiponectin was measured by radioimmunoassay (Linco Research Inc, St Charles, Mo). All samples from each individual were measured in duplicate in one assay. The assay sensitivity for adiponectin was $1.56 \mu \mathrm{g} / \mathrm{mL}$. Intra-assay and interassay coefficients of variation were $3.9 \%$ and $6.6 \%$, respectively.

Leptin-For all samples, leptin was measured by radioimmunoassay (Linco Research). All samples from each individual were measured in duplicate in one assay. The assay sensitivity for leptin was $0.5 \mathrm{ng} / \mathrm{mL}$. Intra-assay and interassay coefficients of variation were $5 \%$ and $7.1 \%$, respectively.

\section{Statistical Analysis}

For statistical analyses and graphing of data from study 1, data from days 2-3 were labeled day 3; from days 6-7, day 7; from days $14-15$, day 15 ; and from days $28-30$, day 30 . All results are expressed as means \pm SEM unless otherwise indicated. A paired $t$ test with a Bonferroni correction was used to determine differences between treatment and baseline values within a group. Changes over time between groups were assessed by a 2-way analysis of variance of hormone levels, with time and group as factors, and were verified with a Tukey's honestly significant difference post hoc test. In addition, differences between groups at a given time point were verified by 2 -sample Student's $t$ tests. For all comparisons, $P \leq .05$ was considered statistically significant.

\section{Results}

\section{Study Populations}

The baseline characteristics of the subjects from the studies are shown in Table 1. In study 1, the subjects receiving Acyline alone were found to have higher baseline BMI, $\mathrm{T}$, and leptin levels than the subjects receiving Acyline + T. There were no significant differences in the baseline characteristics of the subjects in study 2 who received placebo compared with those who received TE (Table 2).
Table 2. Baseline parameters of subjects in study 2 (mean \pm SEM)*

\begin{tabular}{lcc}
\hline & Placebo & TE $600 \mathrm{mg} / \mathrm{wk}$ \\
\hline $\mathrm{n}$ & 12 & 13 \\
Age $(\mathrm{y})$ & $69.2 \pm 1.8$ & $73.0 \pm 2.2$ \\
$\mathrm{BMl}\left(\mathrm{kg} / \mathrm{m}^{2}\right)$ & $32.5 \pm 1.3$ & $30.1 \pm 1.6$ \\
$\mathrm{~T}(\mathrm{nmol} / \mathrm{L})$ & $11.9 \pm 1.4$ & $14.0 \pm 1.7$ \\
Adiponectin $(\mu \mathrm{g} / \mathrm{mL})$ & $13.0 \pm 1.4$ & $14.3 \pm 1.9$ \\
Leptin $(\mathrm{ng} / \mathrm{mL})$ & $8.5 \pm 1.2$ & $9.1 \pm 1.4$ \\
\hline
\end{tabular}

${ }^{*} \mathrm{BMI}$ indicates body mass index; $\mathrm{T}$, testosterone; and TE, testosterone enanthate.

\section{Study 1: Testosterone Deficiency and Adiponectin}

Acyline is a potent GnRH antagonist that, as we have previously reported (Herbst et al, 2002), renders normal young men acutely hypogonadal with serum $\mathrm{T}$ in the castrate range; in this study, we found that all dosage regimens of acyline resulted in nearly undetectable serum gonadotropins within 24 hours after a single dose or multiple doses. This effect persisted for at least 15 days after a dose of $300 \mu \mathrm{g} / \mathrm{kg}$ (Herbst et al, 2004); thereafter, T levels slowly rose back to baseline levels by day 30 postinjection (Figure 1A). Adiponectin was significantly increased above baseline within 7 days of acyline administration, an effect that persisted as long as 30 days following single or multiple doses of acyline (Figure 1B). A maximal increase in adiponectin of $49 \% \pm 5.5 \%$ was seen at day 21 following acyline administration (maximum adiponectin at day 21 of $12.2 \pm 1.0$ compared with $8.6 \pm 0.9 \mu \mathrm{g} / \mathrm{mL}$ at baseline; Figure 1B).

To determine whether the effect of acyline on adiponectin was specifically attributable to the resultant decrease in serum testosterone levels, we measured adiponectin levels in subjects who received TE $100 \mathrm{mg} \mathrm{IM} / \mathrm{wk}$ for 4 weeks in addition to $300 \mu \mathrm{g} / \mathrm{kg}$ of acyline starting on day 0 . In these subjects, serum testosterone levels were maintained within the normal range throughout the treatment period (Figure 1A), and serum adiponectin (Figure 1B) did not change significantly.

Because adiponectin might be affected by changes in body composition, we examined leptin, as a biochemical marker of fat mass, and BMI in subjects receiving acyline. Leptin levels increased significantly in subjects receiving Acyline alone by day 15 (data not shown), an effect that persisted through day 30 (Table 3). Changes in leptin in subjects receiving both acyline and $\mathrm{T}$ (Table 3 ) were not significant. BMI was unchanged in subjects receiving Acyline or Acyline + TE (Table 3), and baseline BMI and change in adiponectin were not correlated.

\section{Study 2: Adiponectin and Supraphysiologic Testosterone}

Because adiponectin levels were sensitive to a rapid decrease in serum $T$, we examined whether increases in serum $\mathrm{T}$ above the normal range would affect adiponectin 

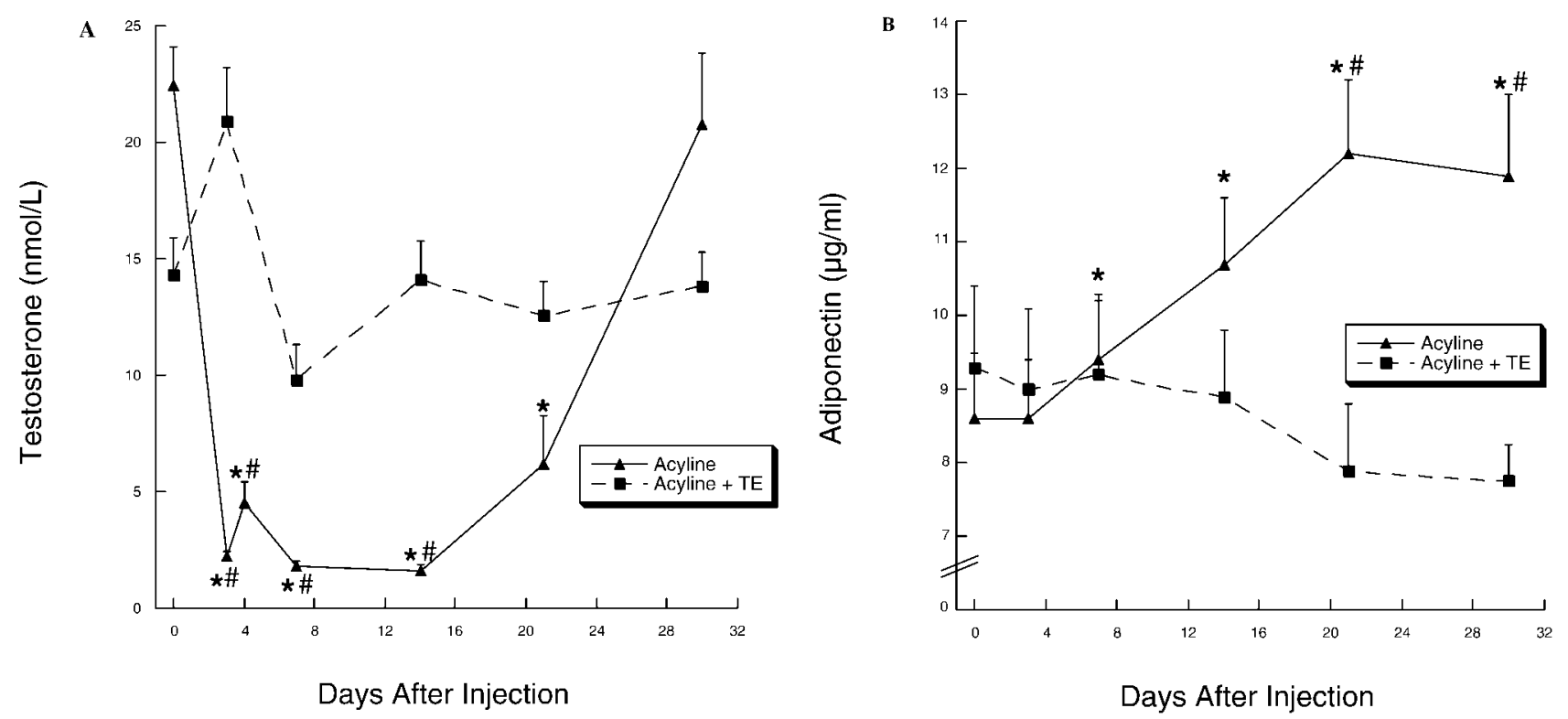

Figure 1. Effect of testosterone deprivation on adiponectin over time. (A) Serum testosterone concentration (nmol/L) after administration of Acyline or Acyline plus TE $100 \mathrm{mg} / \mathrm{wk}$ IM. (B) Serum adiponectin concentration $(\mu \mathrm{g} / \mathrm{mL})$ after administration of Acyline or Acyline + TE $100 \mathrm{mg} / \mathrm{wk}$ IM. ${ }^{*} P<.05$ compared with baseline; $P<.05$ compared with Acyline $+\mathrm{TE}$.

levels. Elderly men received $600 \mathrm{mg}$ of $\mathrm{TE}$ or placebo IM for 3 weeks, and adiponectin levels were measured at baseline and 21 days later. As reported previously (Amory et al, 2002), serum $\mathrm{T}$ in the group receiving exogenous $\mathrm{T}$ was significantly increased above baseline, whereas in the placebo group, $\mathrm{T}$ levels were unchanged (Figure 2A). Adiponectin significantly decreased from baseline in subjects receiving exogenous $\mathrm{T}$ for 21 days, (baseline 14.3 \pm 1.9 compared with $10.8 \pm 1.5 \mu \mathrm{g} / \mathrm{mL}$ on day $21, P<$ .05 vs baseline and placebo), whereas it was unchanged in the placebo group (baseline $12.9 \pm 1.4$ compared with $12.6 \pm 1.3 \mu \mathrm{g} / \mathrm{mL}$ on day 21 ; Figure $2 \mathrm{~B}$ ).

Because adiponectin can be affected by changes in body composition, we examined leptin as a marker of fat mass and BMI in subjects receiving $600 \mathrm{mg}$ TE/wk IM.
Leptin levels decreased in the subjects receiving $\mathrm{T}$ compared with both baseline and placebo, whereas in the placebo group, leptin increased slightly compared with baseline (Table 3). BMI increased significantly over baseline and when compared with the placebo group in subjects receiving $600 \mathrm{mg}$ TE/wk IM (Table 3). There was no correlation between baseline BMI and change in adiponectin.

To determine the time course of adiponectin changes in the setting of supraphysiologic $\mathrm{T}$ levels, weekly adiponectin levels were measured in a subgroup of the subjects receiving TE $600 \mathrm{mg} / \mathrm{wk} \mathrm{IM}(\mathrm{n}=4)$ or placebo ( $=5$ ) who had participated in a substudy of acute lipid effects of high-dose T (Herbst et al, 2003a). A trend toward a decrease in adiponectin by day 14 after testoster-

Table 3. Changes in leptin and body mass index (BMI)*

\begin{tabular}{|c|c|c|c|c|}
\hline & \multicolumn{2}{|c|}{ Leptin, ng/mL } & \multicolumn{2}{|c|}{ BMI, kg/m² } \\
\hline & Baseline & Day 28-30† & Baseline & Day 28-30† \\
\hline \multicolumn{5}{|l|}{ Study 1} \\
\hline Acyline & $5.9 \pm 1.0$ & $8.4 \pm 1.3 \ddagger$ & $26.0 \pm 0.8$ & $26.2 \pm 0.8$ \\
\hline \multirow[t]{2}{*}{ Acyline + TE } & $2.2 \pm 0.5$ & $2.6 \pm 0.6$ & $23.7 \pm 0.9$ & $23.7 \pm 0.9$ \\
\hline & Baseline & Day 21 & Baseline & Day 21 \\
\hline \multicolumn{5}{|l|}{ Study 2} \\
\hline Placebo & $8.5 \pm 1.2$ & $9.7 \pm 1.2 \ddagger$ & $32.5 \pm 1.6$ & $32.3 \pm 1.3$ \\
\hline TE 600 mg/wk IM & $9.1 \pm 1.4$ & $6.1 \pm 0.9 \neq \S$ & $30.1 \pm 1.6$ & $31.0 \pm 1.6 \neq \S$ \\
\hline
\end{tabular}

* TE indicates testosterone enanthate.

$\dagger$ Leptin and BMI were measured on day 28 in the group receiving Acyline + TE and day 30 in the groups receiving Acyline alone.

$\ddagger P<.05$ vs baseline.

$\S P<.05$ vs placebo. 

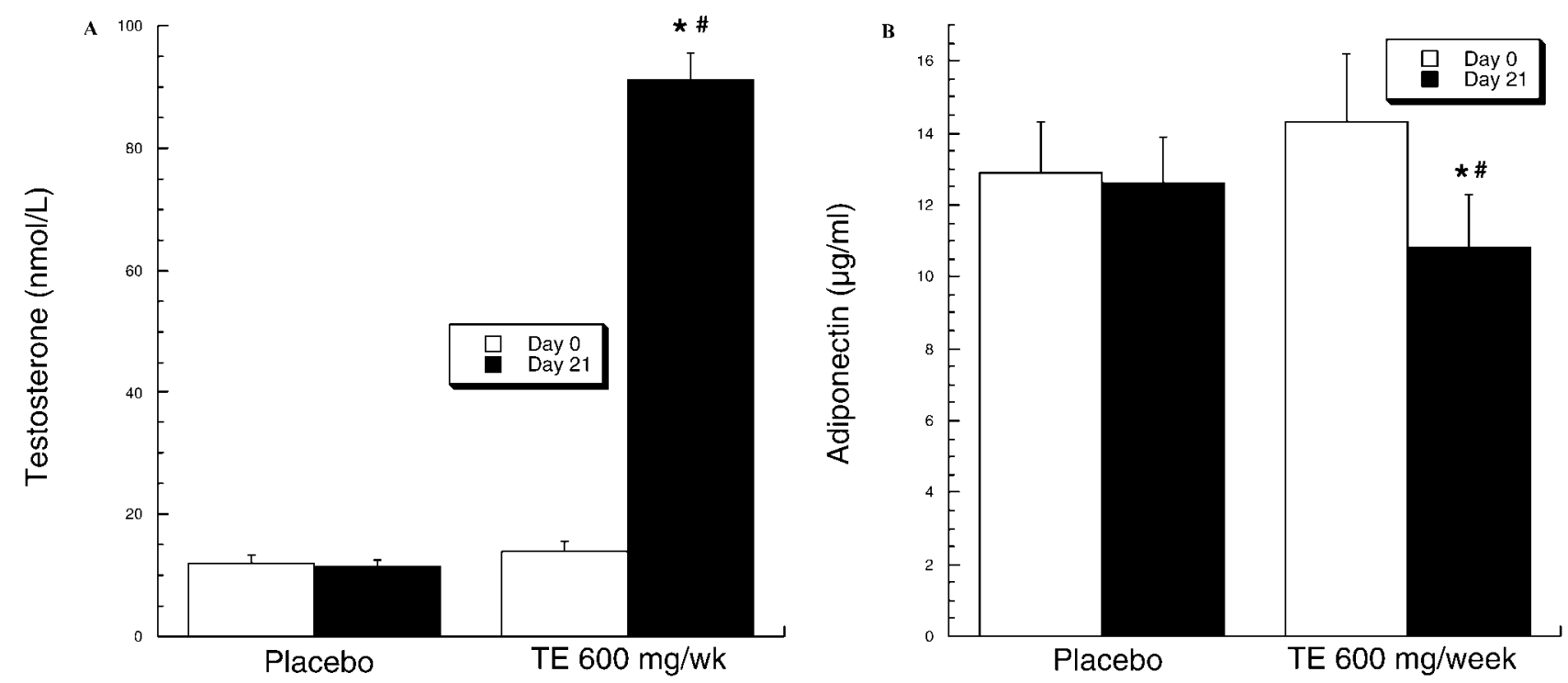

Figure 2. Effect of supraphysiologic testosterone on adiponectin. (A) Serum testosterone concentration (nmol/L) at baseline and 21 days after administration of placebo (white bars) or TE $600 \mathrm{mg} / \mathrm{wk}$ IM (black bars). (B) Serum adiponectin concentration $(\mu \mathrm{g} / \mathrm{mL})$ at baseline and $21 \mathrm{days}$ after administration of placebo (white bars) or TE $600 \mathrm{mg} / \mathrm{wk}$ IM (black bars). ${ }^{*} P<.05$ compared with baseline; \# $P<.05$ compared with placebo.

one administration persisted at day 21 (Figure 3). However in this small subgroup, the differences compared with baseline and placebo did not reach statistical significance. Leptin decreased by $36.3 \% \pm 3.1 \%$ on day 14 and $29.4 \% \pm 9.9 \%$ on day 21 with $\mathrm{T}$ and increased by $24.7 \% \pm 18.3 \%$ on day 14 and $20.3 \% \pm 7.9 \%$ on day 21 in the placebo group $(P<.05)$ in the subgroup analyses, but either group compared with baseline was not significantly different.

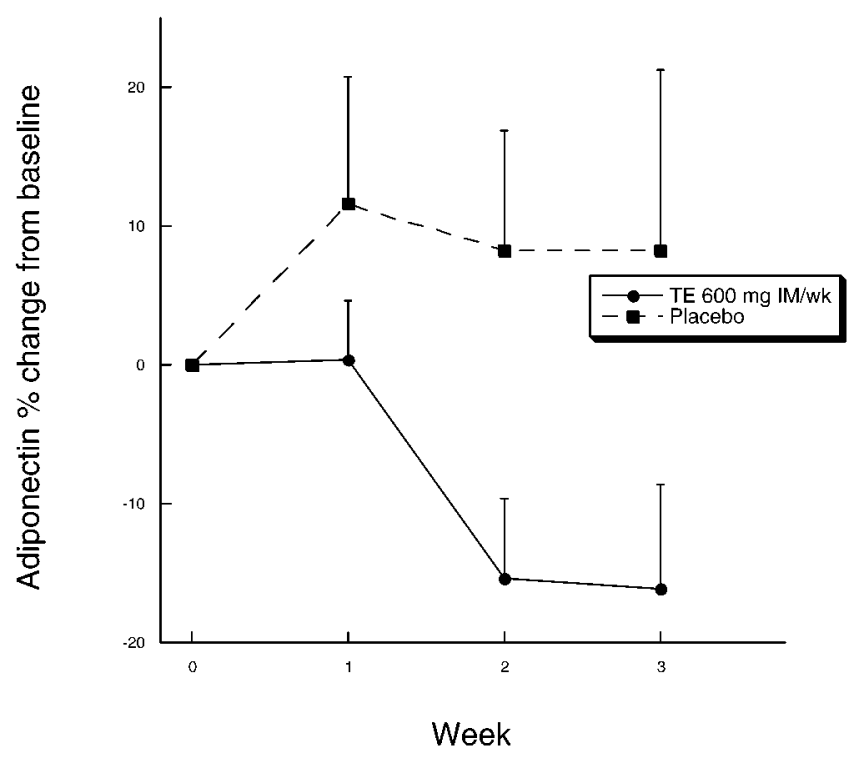

Figure 3. Time course of change in serum adiponectin with supraphysiologic testosterone administration. Solid line, TE $600 \mathrm{mg} / \mathrm{wk} \operatorname{IM}(n=4)$; broken line, placebo $(n=5)$.

\section{Discussion}

In this study, we demonstrated for the first time in normal men that experimentally induced changes in circulating $\mathrm{T}$ levels alter serum adiponectin concentrations. Experimentally induced $\mathrm{T}$ deficiency in normal men lasting as little as 2 weeks results in a gradual and significant rise in serum adiponectin detectable by day 7 after androgen deprivation. This effect persists up to 4 weeks after serum testosterone and gonadotropin levels have normalized (Figure 1; Herbst et al, submitted). The addition of $\mathrm{T}$ to acyline prevented the rise in adiponectin induced by the GnRH antagonist (Figure 2), demonstrating that the effect of acyline on adiponectin is not a result of the peptide itself; nor is it attributable to an absence of luteinizing hormone or follicle-stimulating hormone, but rather a consequence of androgen withdrawal. Our results are consistent with those of Nishizawa et al (2002), wherein an increase in adiponectin was observed 6 weeks after mouse castration and with those of Lanfranco et al (2004), who found higher adiponectin levels in eugonadal men compared with age- and weight-matched hypogonadal men and decreased adiponectin in hypogonadal young men after $\mathrm{T}$ replacement. Furthermore, we demonstrate that administration of supraphysiologic doses of testosterone for as little as 3 weeks, which also profoundly suppresses serum gonadotropins (Amory et al, 2002), decreased serum adiponectin levels by day 21 (Figure 3), providing further evidence that androgens either directly or indirectly (via aromatization to estradiol or $5 \alpha$-reduction to dihydrotestosterone) regulate adiponectin levels in men. 
Our data demonstrate the marked effect of $\mathrm{T}$, its active metabolites (estradiol and dihydrotestosterone), or both on adiponectin in vivo. Even though these analyses used stored serum, the differences we observed are not likely attributable to the instability of adiponectin in stored samples because measurements of adiponectin by radioimmunoassay have been shown to be reproducible in samples stored up to 1 year at $-20^{\circ} \mathrm{C}$ (Pischon et al, 2003). We cannot exclude the possibility that our results are influenced by baseline differences between the study subjects in each group (Tables 1 and 2). Of note, higher baseline adiponectin levels were observed in the older men despite their higher BMI (Table 2). This is likely a function of age because a recent analysis found age to be more strongly related to adiponectin than any other variable analyzed, including BMI and intra-abdominal fat (Cnop et al, 2003). Similar studies in age- and BMI-matched groups would further validate our observations, but we saw changes in adiponectin with $\mathrm{T}$ manipulation in both young and older men, suggesting that the regulatory effect of $\mathrm{T}$ on adiponectin is not age dependent

The mechanism by which $\mathrm{T}$ influences adiponectin is not clear from these studies. It is possible that the effect of $\mathrm{T}$ on adiponectin is mediated through its effects on body composition. $\mathrm{T}$ has been shown to increase lean body mass and decrease fat mass as soon as 4 weeks after administration (Herbst et al, 2003). Similar changes in body composition with administration of supraphysiologic doses of TE are likely to have occurred in this study because we observed a decrease in leptin and an increase in BMI within 21 days (Table 2). Conversely, hypogonadism is associated with increased fat mass and BMI (Smith et al, 2001; Basaria et al, 2002). Consistent with these results, in our study, leptin increased within 30 days of acute hypogonadism. These changes in leptin, and by inference fat mass, were both temporally and positively associated with changes in adiponectin in both of our studies. It is possible that decreases in fat mass result acutely in decreased secretion of adiponectin by adipocytes and, conversely, that acute increases in fat mass result in increases in adiponectin levels. This would be in contrast to cross-sectional studies wherein adiponectin levels correlate inversely with fat mass, abdominal fat mass in particular (Cnop et al, 2003; Ducluzeau et al, 2003), and weight loss is associated with increases in serum adiponectin (Yang et al, 2001). Future studies that include detailed body composition by dual x-ray absorptiometry (DEXA) or computed tomography scan in the setting of androgen manipulation are warranted in determining the mechanism through which $\mathrm{T}$ regulates adiponectin.

Whether sex steroids have a direct effect on adiponectin metabolism, cellular trafficking, or expression by adipocytes is not known. It is possible that androgens de- crease adiponectin expression by sequestering ARA70, a coactivator common to both the androgen receptor (AR) and peroxisome proliferator-activated receptor gamma 1 (PPAR $\gamma$; Heinlein et al, 1999). PPAR $\gamma 1,2$, the AR, and ARA70 are all expressed in human adipocytes (Dieudonne et al, 1998), and ARA70 is upregulated during adipocyte differentiation, a PPAR $\gamma$-mediated process (Yeh and Chang, 1996; Nishizuka et al, 2002). PPAR $\gamma$ agonists, thiazolidinediones, have been shown to increase adiponectin expression (Maeda et al, 2001), likely through a functional PPAR-responsive element in the human adiponectin promoter (Iwaki et al, 2003). In vitro activation of the AR reduces ARA70-dependent expression of a PPAR $\gamma$ reporter gene, suggesting that cross talk might exist between the AR and PPAR $\gamma$ via sequestration of ARA70 within tissues that coexpress both AR and PPAR $\gamma$ (Heinlein et al, 1999). In this model, interaction of the AR with T might compete with PPAR $\gamma$ for ARA70, resulting in reduced expression of PPAR $\gamma$-regulated genes such as adiponectin. Validation of such a model will require further molecular analyses.

The effects of androgens on insulin sensitivity are not well understood. Three months of androgen deprivation mediated by a GnRH agonist in elderly men with prostate cancer increases serum insulin levels (Smith et al, 2001; Dockery et al, 2003), whereas oral T undecanoate increased insulin sensitivity in obese, middle-aged men (Marin et al, 1992a,b). However, studies of androgen supplementation in elderly hypogonadal and eugonadal men have not verified these findings (Friedl et al, 1989; Singh et al, 2002; Liu et al, 2003; Schroeder et al, 2003), and supraphysiologic doses of TE in young healthy subjects do not appear to improve insulin sensitivity (Friedl et al, 1989; Singh et al, 2002). It is possible that although androgens decrease adiponectin, which might decrease insulin sensitivity, the favorable affects of androgens on body composition neutralize this effect with no net change in insulin sensitivity.

We have demonstrated that experimentally induced $\mathrm{T}$ deficiency increases circulating adiponectin, whereas supraphysiologic $\mathrm{T}$ suppresses adiponectin in normal men. We conclude that $T$, its active metabolites, or both suppress circulating adiponectin concentrations and also that androgen administration reduces basal adiponectin concentrations. Whether or not these changes persist long term and what effect they have on insulin sensitivity will be the subject of future research.

\section{Acknowledgments}

The authors thank Arlen Sarkissian and Dorothy McGuinness for performing hormone assays and Marilyn Buscher and Connie Nosbisch for their assistance with the clinical aspects of the studies. 


\section{References}

Amory JK, Chansky HA, Chansky KL, Camuso MR, Hoey CT, Anawalt BD, Matsumoto AM, Bremner WJ. Preoperative supraphysiological testosterone in older men undergoing knee replacement surgery. $J$ Am Geriatr Soc. 2002;50:1698-1701.

Arita Y, Kihara S, Ouchi N, et al. Paradoxical decrease of an adiposespecific protein, adiponectin, in obesity. Biochem Biophys Res Commun. 1999;257:79-83.

Basaria S, Lieb J II, Tang AM, DeWeese T, Carducci M, Eisenberger M, Dobs AS. Long-term effects of androgen deprivation therapy in prostate cancer patients. Clin Endocrinol (Oxf). 2002;56:779-786.

Berg AH, Combs TP, Scherer PE. ACRP30/adiponectin: an adipokine regulating glucose and lipid metabolism. Trends Endocrinol Metab. 2002;13:84-89.

Bhasin S, Storer TW, Berman N, et al. The effects of supraphysiologic doses of testosterone on muscle size and strength in normal men. $N$ Engl J Med. 1996;335:1-7.

Bhasin S, Storer TW, Berman N, et al. Testosterone replacement increases fat-free mass and muscle size in hypogonadal men. J Clin Endocrinol Metab. 1997;82:407-413.

Bhasin S, Woodhouse L, Casaburi R, et al. Testosterone dose-response relationships in healthy young men. Am J Physiol Endocrinol Metab. 2001;281:E1172-E1181.

Cnop M, Havel PJ, Utzschneider KM, et al. Relationship of adiponectin to body fat distribution, insulin sensitivity and plasma lipoproteins: evidence for independent roles of age and sex. Diabetologia. 2003; 46:459-469.

Dieudonne MN, Pecquery R, Boumediene A, Leneveu MC, Giudicelli Y. Androgen receptors in human preadipocytes and adipocytes: regional specificities and regulation by sex steroids. Am J Physiol. 1998;274: C1645-C1652.

Dockery F, Bulpitt CJ, Agarwal S, Donaldson M, Rajkumar C. Testosterone suppression in men with prostate cancer leads to an increase in arterial stiffness and hyperinsulinaemia. Clin Sci (Lond). 2003;104: 195-201.

Ducluzeau PH, Cousin P, Malvoisin E, Bornet H, Vidal H, Laville M, Pugeat M. Glucose-to-insulin ratio rather than sex hormone-binding globulin and adiponectin levels is the best predictor of insulin resistance in nonobese women with polycystic ovary syndrome. $J$ Clin Endocrinol Metab. 2003;88:3626-3631.

Esposito K, Pontillo A, Di Palo C, Giugliano G, Masella M, Marfella R, Giugliano D. Effect of weight loss and lifestyle changes on vascular inflammatory markers in obese women: a randomized trial. JAMA. 2003;289:1799-1804.

Friedl KE, Jones RE, Hannan CJ Jr, Plymate SR. The administration of pharmacological doses of testosterone or 19-nortestosterone to normal men is not associated with increased insulin secretion or impaired glucose tolerance. J Clin Endocrinol Metab. 1989;68:971-975.

Gruenewald DA, Matsumoto AM. Testosterone supplementation therapy for older men: potential benefits and risks. J Am Geriatr Soc. 2003; 51:101-115.

Haffner SM, Shaten J, Stern MP, Smith GD, Kuller L. Low levels of sex hormone-binding globulin and testosterone predict the development of non-insulin-dependent diabetes mellitus in men. MRFIT Research Group. Multiple Risk Factor Intervention Trial. Am J Epidemiol. 1996;143:889-897.

Heinlein CA, Ting HJ, Yeh S, Chang C. Identification of ARA70 as a ligand-enhanced coactivator for the peroxisome proliferator-activated receptor gamma. J Biol Chem. 1999;274:16147-16152.

Herbst KL, Amory JK, Brunzell JD, Chansky HA, Bremner WJ. Testosterone administration to men increases hepatic lipase activity and decreases HDL and LDL size in 3 wk. Am J Physiol Endocrinol Metab. 2003a;284:E1112-E1118.
Herbst KL, Anawalt BD, Amory JK, Bremner WJ. Acyline: the first study in humans of a potent, new gonadotropin-releasing hormone antagonist. J Clin Endocrinol Metab. 2002;87:3215-3220.

Herbst KL, Anawalt BD, Amory JK, Matsumoto AM, Bremner WJ. The male contraceptive regimen of testosterone and levonorgestrel significantly increases lean mass in healthy young men in 4 weeks, but attenuates a decrease in fat mass induced by testosterone alone. J Clin Endocrinol Metab. 2003b;88:1167-1173.

Herbst KL, Coviello AD, Page ST, Amory JK, Anawalt BD, Bremner WJ. A single dose of the potent gonadotropin releasing hormone antagonist acyline suppresses gonadotropins and testosterone for 2 weeks in healthy young men. JCEM. in press.

Hotta K, Funahashi T, Arita Y, et al. Plasma concentrations of a novel, adipose-specific protein, adiponectin, in type 2 diabetic patients. Arterioscler Thromb Vasc Biol. 2000;20:1595-1599.

Hotta K, Funahashi T, Bodkin NL, Ortmeyer HK, Arita Y, Hansen BC, Matsuzawa Y. Circulating concentrations of the adipocyte protein adiponectin are decreased in parallel with reduced insulin sensitivity during the progression to type 2 diabetes in rhesus monkeys. Diabetes. 2001;50:1126-1133.

Iwaki M, Matsuda M, Maeda N, Funahashi T, Matsuzawa Y, Makishima M, Shimomura I. Induction of adiponectin, a fat-derived antidiabetic and antiatherogenic factor, by nuclear receptors. Diabetes. 2003;52: $1655-1663$

Kubota N, Terauchi Y, Yamauchi T, et al. Disruption of adiponectin causes insulin resistance and neointimal formation. J Biol Chem. 2002;277: 25863-25866.

Lanfranco F, Zitzmann M, Simoni M, Nieschlag E. Serum adiponectin levels in hypogonadal males: influence of testosterone replacement therapy. Clin Endocrinol (Oxf). 2004;60:500-507.

Liu PY, Wishart SM, Celermajer DS, Jimenez M, Pierro ID, Conway AJ, Handelsman DJ. Do reproductive hormones modify insulin sensitivity and metabolism in older men? A randomized, placebo-controlled clinical trial of recombinant human chorionic gonadotropin. Eur J Endocrinol. 2003;148:55-66.

Lovejoy JC, Bray GA, Greeson CS, Klemperer M, Morris J, Partington C, Tulley R. Oral anabolic steroid treatment, but not parenteral androgen treatment, decreases abdominal fat in obese, older men. Int $J$ Obes Relat Metab Disord. 1995;19:614-624.

Maeda N, Takahashi M, Funahashi T, et al. PPARgamma ligands increase expression and plasma concentrations of adiponectin, an adipose-derived protein. Diabetes. 2001;50:2094-2099.

Marin P, Holmang S, Jonsson L, Sjostrom L, Kvist H, Holm G, Lindstedt G, Bjorntorp P. The effects of testosterone treatment on body composition and metabolism in middle-aged obese men. Int J Obes Relat Metab Disord. 1992a;16:991-997.

Marin P, Krotkiewski M, Bjorntorp P. Androgen treatment of middleaged, obese men: effects on metabolism, muscle and adipose tissues. Eur J Med. 1992b;1:329-336.

Nishizawa H, Shimomura I, Kishida K, et al. Androgens decrease plasma adiponectin, an insulin-sensitizing adipocyte-derived protein. Diabetes. 2002;51:2734-2741.

Nishizuka M, Tsuchiya T, Nishihara T, Imagawa M. Induction of Bach1 and ARA70 gene expression at an early stage of adipocyte differentiation of mouse 3T3-L1 cells. Biochem J. 2002;361:629-633.

Pischon T, Hotamisligil GS, Rimm EB. Adiponectin: stability in plasma over 36 hours and within-person variation over 1 year. Clin Chem. 2003;49:650-652.

Rajala MW, Scherer PE. Minireview: the adipocyte - at the crossroads of energy homeostasis, inflammation, and atherosclerosis. Endocrinology. 2003;144:3765-3773.

Schroeder ET, Singh A, Bhasin S, et al. Effects of an oral androgen on muscle and metabolism in older, community-dwelling men. Am J Physiol Endocrinol Metab. 2003;284:E120-E128. 
Shapiro L, Scherer PE. The crystal structure of a complement-1q family protein suggests an evolutionary link to tumor necrosis factor. Curr Biol. 1998;8:335-338.

Singh AB, Hsia S, Alaupovic P, et al. The effects of varying doses of $\mathrm{T}$ on insulin sensitivity, plasma lipids, apolipoproteins, and C-reactive protein in healthy young men. J Clin Endocrinol Metab. 2002;87: 136-143.

Singh R, Artaza JN, Taylor WE, Gonzalez-Cadavid NF, Bhasin S. Androgens stimulate myogenic differentiation and inhibit adipogenesis in $\mathrm{C} 3 \mathrm{H} 10 \mathrm{~T} 1 / 2$ pluripotent cells through an androgen receptor-mediated pathway. Endocrinology. 2003;144:5081-5088.

Smith JC, Bennett S, Evans LM, et al. The effects of induced hypogonadism on arterial stiffness, body composition, and metabolic parameters in males with prostate cancer. J Clin Endocrinol Metab. 2001; 86:4261-4267.

Snyder PJ, Peachey H, Berlin JA, et al. Effects of testosterone replacement in hypogonadal men. J Clin Endocrinol Metab. 2000;85:2670_ 2677.
Woodhouse LJ, Gupta N, Bhasin M, Singh AB, Ross R, Phillips J, Bhasin $\mathrm{S}$. Dose-dependent effects of testosterone on regional adipose tissue distribution in healthy young men. J Clin Endocrinol Metab. 2004; 89:718-726.

Yamauchi T, Kamon J, Waki H, et al. The fat-derived hormone adiponectin reverses insulin resistance associated with both lipoatrophy and obesity. Nat Med. 2001;7:941-946.

Yang WS, Lee WJ, Funahashi T, et al. Weight reduction increases plasma levels of an adipose-derived anti-inflammatory protein, adiponectin. $J$ Clin Endocrinol Metab. 2001;86:3815-3819.

Yeh S, Chang C. Cloning and characterization of a specific coactivator, ARA70, for the androgen receptor in human prostate cells. Proc Natl Acad Sci U S A. 1996;93:5517-5521.

Yu JG, Javorschi S, Hevener AL, Kruszynska YT, Norman RA, Sinha M, Olefsky JM. The effect of thiazolidinediones on plasma adiponectin levels in normal, obese, and type 2 diabetic subjects. Diabetes. 2002; 51:2968-2974. 